\title{
BRITISH MAMMALS MAMMALS OF CHESHIRE
}

\author{
By $\Lambda$. W. Boyd
}

Cheshire is a county of varied character. On the east the moorlands bordering Yorkshire, Derbyshire and Staffordshire rise at one point to over 1,900 feet; then comes the fertile plain, which includes the Forest of Delamere and many large parks; further west is the peninsula of Wirral, bounded on either side by the estuaries of Mersey and Dee, and culminating in a short coastline and the three islands of Hilbre.

The mammals of the county are much what one would expect in any inland county with this varicty of habitat; in addition a few scafaring animals frequent the mouth of the Dee, or are storm-driven to the shallow waters of the coast of Wirral.

\section{Cimiroptera}

The Cheshire bats, known locally as "Bit-bats", were well worked out by those two great naturalists, T. A. Coward and Charles Oldham, and little has been added to our knowledge of them since the publication of The Fauna of Cheshire in 1910, and a later paper by Coward in 1919. Both these publications have been consulted and a great many other facts in this paper have been drawn from them. The noctule is not uncommon and is widely distributed; on 1st March, 1948, I watched one flying in the bright sunshine over the frozen mere at Tabley during a spell of very cold weather. Leisler's bat has been recorded from at least three places. The pipistrelle is common generally but only one specimen of Natterer's bat is on record. Daubenton's bat, on the other hand, has been known in Cheshire for over 100 years and has been found from the hills in the east to Wirral in the west. The whiskered bat is also found throughout the county and has been recorded comparatively recently from the valley of the Goyt and from Longdendale in the hilly country. Coward found the long-eared bat to be abundant throughout Cheshire and one example of the barbastelle from Cheshire is preserved in the British Museum.

\section{INSECTIVORA}

Hedgehogs, which some of my neighbours call "urchants" (though Coward in 1910. said the name was then obsolete) are abundant generally, despite their slaughter by those who still believe they milk the cows, and despite their frequent deaths on the roads, where their habit of rolling themselves up 
as soon as a light shines on them gives them little chance of avoiding rapid traffic. Churchwardens' accounts at the end of the seventeenth century show their abundance then and the intolerance of the countryman: for example, at Bunbury payment was made for almost 8,000 in 26 years; at Frodsham 390 were killed in the year 1690; and at Great Budworth more than 1,000 in five years at the end of that century. In 1672 the churchwardens at Frodsham (for one year only) recorded them as porcupines! The mole is abundant, but avoids some of the heavy land. It varies in number from year to year and was very numerous on some fairly light soil in 1955 . It, too, occurs in churchwardens' accounts but seldom in the seventeenth and eighteenth centuries; in the nineteenth century it was killed more systematically. In 1732 at Prestbury only 6d. a dozen was paid for them, but $1 \frac{1}{2} d$. each " if killed in a garden, so called, cultivated and used". They were then often called " mouldywarps ", a name still used occasionally.

The common shrew is as common as its name implies, but is seen more often dead than alive, but the lesser shrew, found in various places in the hills, in mid-Cheshire and in Wirral, is less common. I trapped one at a beehive. 'The water shrew is not uncommon throughout.

\section{Carnivora : Fissipedia}

Badgers are far more widely distributed than is generally realized. Their nocturnal habits ensure their being rarely seen except by those abroad at night. 'They are well established in much of the plain, often in good numbers. In Delamere forest they are plentiful, but there and in other parts of the county the pest officers gas them regularly. Many landowners are proud to give them protection. 1s. a head was paid for their destruction in the seventeenth century.

Otters also are widely distributed (but rarely seen) in midCheshire in the rivers and meres. In the seventecnth century only $4 d$. a piece was paid for them by the churchwardens, but in $17372 s$. was paid for an old one at Frodsham, and in 1730 at Prestbury the remarkably high reward of $7 s .6 d$.

Weascls and stoats are both abundant, as a visit to any gamekeeper's larder. will show. 'The stoat is the more often seen, but weasels are little less numerous and wiped out a colony of tree-sparrows in my nest-boxes, having discovered that they could enter by a hole too small for a house-sparrow. I have watehed a fight between a stoat and a rat in which the stont was victor. The polecat is extinct in the county, where once it 
was a well-established resident. It survived until about 1880 and there is some evidence, quoted by Coward, of one or two that were killed in N.E. Cheshire between 1892 and 1900, but these may have been polecat-ferrets that had escaped. I have talked to three old neighbours of mine who remembered them. Polecats bred on Bartington Heath about 100 years ago, before it was reclaimed; the two latest in the Great Budworth district were : one killed on Whitley Reed in 1878 or 1879 and another seen at Frandley about the same date. It is still spoken of as a "filmont", the name by which it is recorded in the Weaverham churchwardens' accounts; there at the edge of Delamere Forest, 1d. each was paid for thirty-nine filmonts between 1674 and 1681, and many more were killed in 1682.

The marten is now extinct, but is said to have survived in the forest until the early part of the nineteenth century. The last of which there is real evidence was shot at Eaton on the Dee in 1891 and is now in the Grosvenor Museum at Chester.

Foxes, as may be expected in a hunting county, are plentiful and there are many in the hills where the fox-hunt does not function. 'They are not so numerous as they were before 1939, for many more farmers now own their own land and keep them down. One summer in the 1930's I reckoned that there were 50 within half a mile of my house. Churchwardens' accounts show that there were fewer in the seventeenth century, before they were preserved for the hunt. A shilling each was paid for foxes' heads as early as 1601. In 45 years in the second half of the seventeenth century in the parish of Bunbury there were more payments than elsewhere and they averaged five a year, but there were fewer in other parishes. 'Then came the planting of fox-coverts, many of which are still maintained for their original purpose, and a great increase in the number of foxes. The recent virtual eradication of rabbits, their chief food, will soon automatically reduce the number of foxes.

\section{RoDENTIA}

There has been a great reduction in the number of red squirrels since Coward in $\mathbf{1 9 1 0}$ described them as abundant in the wooded parts of the county. They are still prevalent in Delamere Forest and at least until recently were found in Wirral, but have disappeared from many parts where their place has been taken by the grey squirrel. This American animal was turned down in the cast of the county between 1907 and 1910, and in Dunham Park in 1910. It soon spread and became numerous in many places. An carly one shot at High Leigh was clnimed by the keeper 
to be a cross between a squirrel and a rabbit ! During the 1930's it increased inordinately and the keeper at Arley, where 12 were killed in 1934, shot 180 in 1938. A keeper at Oulton saw one kill several young red squirrels in their nest before he shot it.

The dormouse is said to have been found regularly in the 1880's and 1890's, but is now unknown, as is the harvest mouse, though there are odd records of its occurrence in the last century. The wood or long-tailed ficld mouse is really abundant and can become very troublesome; on a farm, where new strains of wheat are raised, it has caused considerable damage and in years when it is plentiful will raid anything from bulbs to beehives. The house-mouse also is far too plentiful and not only in houses, as anyone can testify who has attended the threshing of a corn-stack. The barn-owl does tremendous destruction among these two mice.

The black rat occurs at Birkenhead, as at other ports. 'The latest found inland was trapped in 1943 at Northwich, whither it had obviously come on a boat from Merseyside and up the river Weaver. The brown rat is a shocking pest in town or country. The water vole is found by many streams and meres. The field and bank voles are both abundant and at times destruetive, though $I$ have not known of any serious infestation in the Cheshire plain. Pellets from a pair of barn owls in a loft in my farmyard in the first three months of a year were analysed by Mr. F. II. Lancum; they contained remains of 87 field and bank voles as well as those of other rodents, birds and beetles. 'The hare is not nearly so plentiful as it was before the passing of the Ground-game Act, but is to be found throughout the county in fair numbers. In the 21 years between 1860 and 1880 over 2,000 were shot on the Arley estate where there are now comparatively few. The blue hare, introduced to the East Cheshire moors in 1860, died out but was reintroduced in $\mathbf{1 8 8 0}$ and has flourished since then. Mr. Denis Midwood tells me that it is still quite common on the Longdendale moors. Rabbits, so widely prevalent until quite recently, were attacked by myxomatosis only threc or four months ago in my own district. 'The have been wiped out in many parts, but $I$ have seen a few healthy ones in the last two or three weeks (September, 1955). It remains to be seen if any will survive.

\section{UNGULATA}

The red deer in the parks at Lyme, Tatton and Doddington are presumed to be of the indigenous Cheshire stock, emparked 
long ago. Fallow deer, although not indigenous animals, existed in Cheshire in a wild state in the seventeenth century and are now kept in several parks.

There remain the seafaring mammals of the estuaries and few miles of coast.

\section{Cannivona : Pinnipedia}

Both common and grey seals frequent the sandbanks at the mouth of the Dee estuary where they can be watehed from Filbre Island, forty and more at a time, or swimming close to the island itself. A hooded seal, a rare straggler to the British Isles, was captured on the shore of the Mersey estuary at Frodsham in February, 1873, and later preserved in the Liverpool Muscum.

\section{Cetacea}

Except for the porpoise these animals are only casual stragglers to the Cheshire coast.

In 1863 a hump-backed whale was stranded in the Mersey Estuary; the bottle-nosed whale has reached the estuaries and the coast at least ten times; in 1876 a grampus or killer whale was stranded at West Kirby. The porpoise is often scen off Hoylake and Hilbre and has been known to travel up the Mersey as far as Latchford, above Warrington. Both the dolphin and the white-bealed dolphin have been stranded on the Cheshire shore, the latter in 1862. As recently as 15th March, 1955 , several of us watched a number of dolphins of some species swimming past Hilbre Island.

Such are the mammals of Cheshire to-day. Gone are the wolves that attacked the red deer in the fourteenth century and are said to have survived until the fifteenth. The wild boar is remembered only because there is a valley called Wildboarclough in the hills. The roc decr was certainly here in Norman times. But a county on the southern border of such centres of population as Stockport, Manchester, Liverpool and Birkenhead will do well if it can keep what it has now. 